J. Clin. Chem. Clin. Biochem.

Vol. 24, 1986, pp. 647-650

(C) 1986 Walter de Gruyter \& Co.

Berlin · New York

\title{
Determination of Clobazam and Its N-Demethyl Metabolite in Serum of Epileptic Patients
}

\author{
By Maria Isabel Arranz Peña
}

Servicio de Bioquimica del Hospital "Ramon y Cajal", Madrid, Spain and

Enrique Saenz Lope

Servicio de Neurologia del Centro Nacional de Rehabilitacion, Madrid, Spain

(Received October 28, 1985/March 14, 1986)

Summary: We describe a gas-liquid chromatographic method, using a nitrogen-specific detector, which is suitable for the simultaneous quantitation of clobazam and its main metabolite $\mathrm{N}$-demethyl clobazam in the serum of epileptic patients treated with other anticonvulsant co-medication. Flunitrazepam (internal standard) is added to the sample and after extraction with a toluene/ethyl acetate mixture $(3+1$ by vol), the organic extract is evaporated and the residue is reconstituted in a small volume of solvent and chromatographed on a 3\% SP2250 column. The sensitivity limits are about 2 to $5 \mu \mathrm{g}$ per liter of original sample.

\section{Bestimmung von Clobazepam und seines N-Demethyl-Metaboliten im Serum von Epileptikern}

Zusammenfassung: Wir beschreiben eine gaschromatographische Methode mit Stickstoff-spezifischer Detektion zur gleichzeitigen quantitativen Bestimmung von Clobazepam und seines Hauptmetaboliten N-Demethylclobazepam im Serum von Epileptikern, die zugleich mit anderen Antikonvulsiva behandelt wurden. Flunitrazepam wird als interner Standard zur Probe hinzugefügt. Nach Extraktion mit Toluol/Ethylacetat (Volumina, $3+1$ ) wird die organische Phase zur Trockne gebracht. Der Rückstand wird in einem kleinen Volumen Lösungsmittel aufgenommen und an einer 3\% SP 2250-Säule chromatographiert. Die Empfindlichkeit liegt bei $2-5 \mu \mathrm{g} / 1$ Ausgangsprobe.

\section{Introduction}

Clobazam, a 1,5-benzodiazepine, is marketed in several European countries as an anxiolytic. Its antiepileptic properties have recently been documented in animals $(1,2)$ and in man $(3,4)$. For the quantitation of clobazam in biological fluids, several HPLC (5) and gas-liquid chromatographic methods $(6-9)$ have been published. Gas-liquid chromatography is a valuable tool in therapeutic drug level monitoring because of its versatility in qualitative and quantitative analysis of a wide variety of drugs. Moreover, for routine determinations in a clinical laboratory, gas-liquid chromatography with a nitrogen-specific detector is preferred to the usual flame ionization detector and to the electron capture detectors because of the low concentration of clobazam in serum. The gas-liquid chromatographic method described for the determination of clobazam and its major metabolite, $\mathrm{N}$ demethyl clobazam, uses diazepam as internal standard (6). When clobazam as antiepileptic agent was used in association with other anticonvulsants (e. g. phenobarbital, phenytoin, carbamazepine...), we observed a peak that coelutes with diazepam in the serum of patients with phenytoin co-medication. Our purpose was to develop a simple and fast method for the determination of clobazam and $\mathrm{N}$-demethyl clobazam that is fully specific in the presence of other anticonvulsant drugs. 


\section{Materials and Methods}

\section{Equipment}

A 3920B gas chromatograph equipped with glass-lined heated injector and detector jets was used (Perkin Elmer Corp., Norwalk, CT 06856), the chromatography glass column was a $2 \mathrm{~m}$ $\times 2 \mathrm{~mm} 3 \%$ SP 2250 on $100 / 120$ mesh Supelcoport (packing 1878, Supelco Bellefonte $\mathrm{Pa}$.) plugged with glass wool treated with phosphoric acid.

\section{Blood collection tubes}

Evacuated blood collection tubes were used: Venojet red stopper tube (Kimble-Terumo Inc., Elkton, MD 21921 exp. 3-87), Vacutainer tubes-red stopper (Becton Dickinson Rutherford, NJ 07070 lots $4 Z 019$ and 6430 4W022 exp. 12-86, respectively).

\section{Reagents and standards}

Ethyl acetate was glass distilled (Burdick \& Jackson, Muskegon MI 49442). Toluene was p. a. grade (Merck, Darmstadt, F.R.G.). Clobazam and N-demethyl clobazam were kindly supplied by Hoechst Aktiengesellschaft (6230 Frankfurt, Main 80). Flunitrazepam was obtained as a gift from Hoffmann-La Roche (Inc. Nutley, NJ 07110). Stock standards: these were prepared in ethyl acetate to obtain a concentration of $100 \mathrm{mg} / \mathrm{l}$ for clobazam, $\mathrm{N}$-demethyl clobazam and flunitrazepam.

Working standards: these were prepared in ethyl acetate in the range $10-150 \mathrm{ng} / \mathrm{l}$ (clobazam) and 50-450 ng/l (N-demethyl clobazam.

Internal standard solutions: this was prepared in ethyl acetate to give a concentration of $200 \mu \mathrm{g} / \mathrm{l}$.

Extraction solvent: toluene/ethyl acetate $(3+1$ by vol).

\section{Procedure}

Column preparation: the column was conditioned at $300^{\circ} \mathrm{C}$ for $24 \mathrm{~h}$ with a nitrogen flow rate of $30 \mathrm{ml} / \mathrm{min}$. At the end, it was primed by injecting $50 \mu \mathrm{g}$ egg lecithin in benzene several times. The use of this phospholipid as a priming agent gives a greater peak resolution. At the beginning of each working day $50 \mu \mathrm{g}$ of lecithin three times were injected to prime the column. Chromatographic conditions: oven temperature, isothermal $280^{\circ} \mathrm{C}$; injection port temperature, $350^{\circ} \mathrm{C}$; interface temperature, $325^{\circ} \mathrm{C}$; nitrogen flow rate, $30 \mathrm{ml} / \mathrm{min}$. Detector nitrogen mode: hydrogen flow rate, $4 \mathrm{ml} / \mathrm{min}$; air flow rate, $60 \mathrm{ml} / \mathrm{min}$; detector current bead setting, 5.4; attenuation, $1 \times 32$.

Determination of clobazam and $N$-demethyl clobazam: internal standard $(500 \mu \mathrm{l})$ is added to a glass stoppered centrifuge tube, then evaporated to dryness at $40^{\circ} \mathrm{C}$ under mildly reduced pressure. Serum $(500 \mu l)$ is then added and mixed with vortexing for $30 \mathrm{~s}$. Extraction solvent $(5 \mathrm{ml})$ is added and after mixing (vortex) for $15 \mathrm{~min}$, the tube contents are centrifuged at 5000 $\min ^{-1}$ for $5 \mathrm{~min}$; the upper organic layer is decanted and evaporated to dryness. Then the residue is dissolved in ethyl acetate $(50 \mu \mathrm{l})$ and 2.5 to $5.0 \mu \mathrm{l}$ are injected into the chromatograph. Quantification is based on the peak-height ratio of the analyte to the internal standard.

\section{Results}

\section{Chromatograms}

Figure 1 shows a typical chromatogram obtained by the reported procedure from extracts of: a) serum blank;

b) serum from a patient who was taking phenytoin, phenobarbital and primidone as anticonvulsant; and c) a serum sample from a patient who was taking clobazam together with phẹnytoin, phenobarbital and primidone.

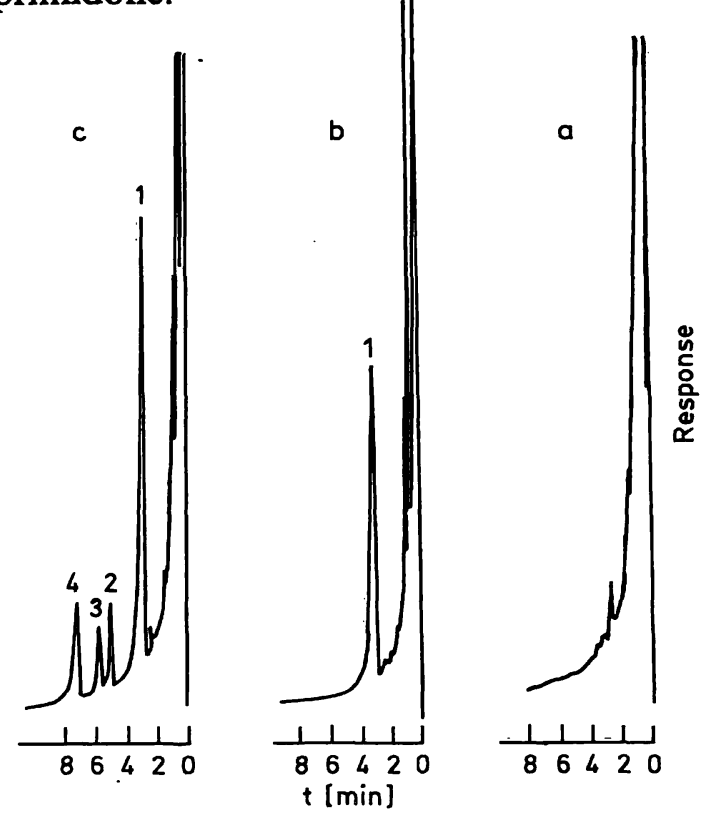

Fig. 1. Chromatograms after extraction from serum with toluene/ethyl acetate (3/1 by vol), containing flunitrazepam as internal standard.

a) Extract of serum blank.

b) Extract of serum of a patient receiving phenobarbital, phenytoin and primidone as anticonvulsant.

c) Extract of serum of a patient receiving clobazam together with phenobarbital, phenytoin and primidone. The peaks shown are:

1) peak caused by the comedication with phenytoin,

2) clobazam $(122 \mathrm{ng} / \mathrm{l})$,

3) flunitrazepam,

4) $\mathrm{N}$-demethyl clobazam (290 ng/l).

\section{Linearity}

We investigated the linearity of the peak-height ratios versus serum drug concentrations (fig. 2 ) in the following ranges: $10-150 \mathrm{ng} / \mathrm{l}$ for clobazam and $50-450 \mathrm{ng} / \mathrm{l}$ for $\mathrm{N}$-demethyl clobazam. The results obtained by using a linear regression analysis were:

clobazam:

slope $=0.009 \quad$ y-intercept $=0.012 \quad r \rightleftharpoons 1.00$

$\mathrm{N}$-demethyl clobazam:

slope $=0.003 \quad$ y-intercept $=0.000 \quad r=0.999$

\section{Precision}

The precision of the method was determined by assaying serum samples wich contained known quantities of the drugs. As shown in table 1 within-day precision ranged from 1.4 to 6.8 , between-day precision ranged from 5.7 to 7.1 and, run-to-run precision between 3.8 and 4.3. 


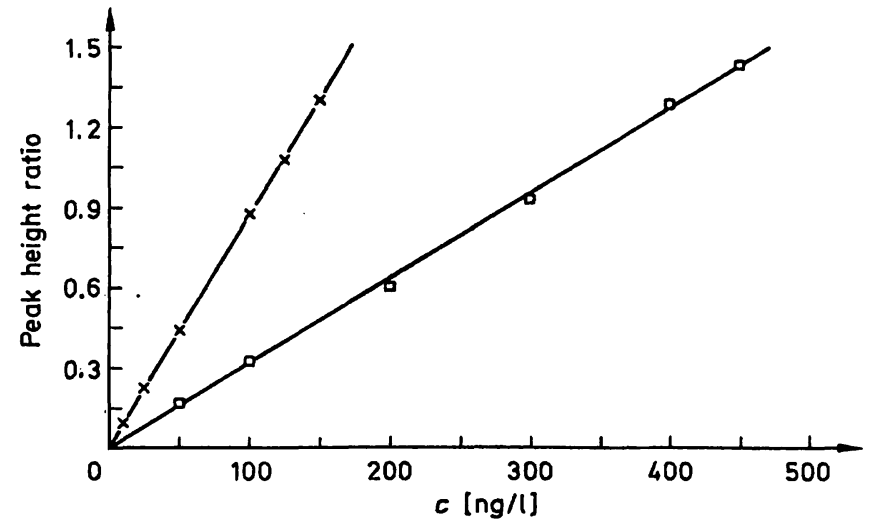

Fig. 2. Peak height ratio of clobazam $(x)$ and N-demethyl clobazam $(\square)$ to internal standard vs clobazam and $\mathrm{N}$ demethyl clobazam concentrations in serum. The regression equation for clobazam was: $y=0.009 \times+0.012$, for N-demethyl clobazam it was: $y=0.003 \times+0.000$.

Tab. 1. Precision for simultaneous determination of drugs in serum.

\begin{tabular}{|c|c|c|c|c|}
\hline \multirow[t]{2}{*}{ Drug } & \multicolumn{2}{|c|}{ Clobazam } & \multicolumn{2}{|c|}{$\begin{array}{l}\text { N-demethyl } \\
\text { clobazam }\end{array}$} \\
\hline & $\begin{array}{l}\text { Mean } \\
(\mathrm{ng} / \mathrm{l})\end{array}$ & $\begin{array}{l}\text { CV } \\
(\%)\end{array}$ & $\begin{array}{l}\text { Mean } \\
\text { (ng/l) }\end{array}$ & $\begin{array}{l}\text { CV } \\
(\%)\end{array}$ \\
\hline $\begin{array}{l}\text { Within-day } \\
(n=14)\end{array}$ & $\begin{array}{r}13 \\
32 \\
114 \\
183\end{array}$ & $\begin{array}{l}4.4 \\
4.2 \\
2.9 \\
1.4\end{array}$ & $\begin{array}{r}57 \\
112 \\
302 \\
459\end{array}$ & $\begin{array}{l}6.8 \\
4.9 \\
3.9 \\
4.4\end{array}$ \\
\hline $\begin{array}{l}\text { Between-day } \\
(\mathrm{n}=10) \\
\text { Run to run }\end{array}$ & $\begin{array}{r}235 \\
94 \\
99\end{array}$ & $\begin{array}{l}6.3 \\
7.0 \\
3.8\end{array}$ & $\begin{array}{l}758 \\
251 \\
381\end{array}$ & $\begin{array}{l}5.7 \\
7.1 \\
4.3\end{array}$ \\
\hline
\end{tabular}

\section{Recovery}

We determined the analytical recovery of the assayed drugs from serum by comparing the peak-height ratios of extracted samples and internal standard with those of equivalent amounts of drugs and internal standard chromatographed directly. Recoveries were 95\%.

\section{Sensitivity}

The lowest concentration of clobazam and N-demethyl clobazam detectable in serum, defined as a signal to noise ratio of 3 , was 2 to $5 \mu \mathrm{g} / 1$ of the original sample when $1 \mathrm{ml}$ serum wạs extracted.

\section{Interferences}

Table 2 shows the retention time of the drugs checked for potential interference relative to the internal standard. None of these drugs coelutes with clobazam, $\mathrm{N}$-demethyl clobazam or internal standard.

The tubes used for blood collection (see Materials and Methods) contain no contaminants that can affect the analysis of the tested drugs.
Tab. 2. Relative retention times (internal standard $=1.000$

\begin{tabular}{ll}
\hline Drug & Relative retention time \\
\hline Carbamazepine & 0.17 \\
Phenobarbital & 0.17 \\
Nortriptyline & 0.20 \\
Amitriptyline & 0.23 \\
Nomifensine & 0.26 \\
Doxepine & 0.26 \\
Demethyl imipramine & 0.28 \\
Medazepam & 0.33 \\
Maprotyline & 0.36 \\
Mianserine & 0.36 \\
Clomipramine & 0.40 \\
Primidone & 0.51 \\
Phenytoin & 0.56 \\
Diazepam & 0.58 \\
Chlordiazepoxide & 0.81 \\
Clobazam & 0.88 \\
Flurazepam & 1.16 \\
N-demethyl clobazam & 1.24 \\
Bromazepam & 1.31 \\
Clonazepam & 2.26 \\
\hline
\end{tabular}

\section{Studies with patient samples}

To assess the performance of the procedure under routine conditions, we determined clobazam and $\mathrm{N}$ demethyl clobazam in the serum of 25 epileptic patients in a dosage range of 0.5 to $1.5 \mathrm{mg} / \mathrm{kg}$ body weight and a variety of co-medication. We measured clobazam levels of 20 to $260 \mathrm{ng} / \mathrm{l}$, and $\mathrm{N}$-demethyl clobazam levels of 200 to $11000 \mathrm{ng} / \mathrm{l}$.

\section{Discussion}

The method we present uses an internal standard of similar chemical structure to clobazam and has the advantage over the published gas-liquid chromatographic method that it permits quantitation of clobazam and N-demethyl clobazam in the serum of epileptic patients with concurrent administration of clobazam and other antiepileptic drugs.

The method used is a single neutral extraction from serum, followed by evaporation of the organic solvent and injection of the redissolved residue directly into the chromatograph. The blank serum samples are free of contaminants in the areas corresponding to the retention time of clobazam, $\mathrm{N}$-demethyl clobazam and internal standard. The patient results obtained agree with those of other authors with respect to the large clearance of clobazam by hepatic demethylation (10), yielding the metabolic product $\mathrm{N}$-demethyl clobazam. Chronic treatment with clobazam leads to an accumulation of very high values of serum $\mathrm{N}$-demethyl clobazam, and under these conditions its concentration can be estimated by the use of the same internal standard with appropriate modification of the calibration curve. 


\section{References}

1. Chapman, A. G., Horton, R. W. \& Meldrum, B. S. (1978) Epilepsia 19, 293-295.

2. Meldrum, B. S., Chapman, A. G. \& Horton, R. W. (1979) Br. J. Clin. Pharmacol. 7, 55S-60S.

3. Gastaut, H. (1978) Nouv. Press. Med. 7, 2400.

4. Gastaut, H. \& Low, M. D. (1979) Epilepsia 20, 437-446.

5. Tomasini, H. L., Bun, H., Coassolo, Ph., Aubert, C. \& Cano, J. P. (1985) J. Chromatogr. 343, 2, 369-373.

6. Hajdu, P., Uihlein, M. \& Damm, D. (1980) J. Clin. Chem. Clin. Biochem. 18, 209-214.
7. Ruu, W., Badian, M., Christ, O., Hajdu, P., Kulkarni, R. D., Taeuber, K., Uiblein, M., Bender, R. \& Vanderbeke, O. (1979) Br. J. Clin. Pharmacol. 7, 51S = 57S.

8. Rupp, W: (1976) Hoechst AG Internal Report.

9. Chris, O. \& Rupp, W. (1972) Hoechst AG Internal Reports. 10. Volz, M., Christ, O., Kellner, H. M., Kuch, H., Fehlhaber, H. W., Gantz, D., Hajdu, P. \& Cavagna, F. (1979) Br. J. Clin. Pharmacol. 7, 41S-50S.

Maria Isabel Arranz Peña

Biochemistry Service

"Ramon y Cajal" Hospital

Carretera de Colmenar Km 9100

Madrid

Spain 